\title{
MAJIME: A Learning Media for Japanese Reading Comprehension
}

\author{
Azizia Freda Savana ${ }^{1, *}$ Annisa Shofaya Rizki Pradana ${ }^{2}$
}

\author{
${ }^{1}$ Universitas Muhammadiyah Yogyakarta, Yogyakarta, Indonesia \\ ${ }^{2}$ Universitas Muhammadiyah Yogyakarta, Yogyakarta, Indonesia \\ *Email: aziziafreda@umy.ac.id
}

\begin{abstract}
MAJIME is an application provider of digital books about children's fairy tales in Japan. The research determines the effectiveness of MAJIME (Mari Rajin Membaca/Let's Read Eagerly) teaching media to improve students' understanding of Japanese texts. This application is implemented in the extracurricular program at SMAN 7 Yogyakarta, Indonesia. The study employed an experimental method in which data obtained from pretest and posttest results. Data were carried out in the control and experimental class. This research also used non-test data in questionnaires to determine the participant's responses to the MAJIME application. The alternative hypothesis used that reads Ha was accepted. H0 rejected if t-test $>t$-value and normalized gain1> normalized gain2 in this study was proven. The t-test obtained was 3.175, highest than the set value of 2,119, and the experimental class gain obtained by 0.07 was higher than the control class gain of 0.56. In conclusion, MAJIME as teaching media was effective in improving student's understanding of reading Japanese texts.
\end{abstract}

\section{Keywords: Effectiveness, Android Application, Japanese Reading Comprehension, Digital books}

\section{INTRODUCTION}

The development of technology and science today has progressed very rapidly. The latest technological discoveries mark this. Recent findings that have emerged will shift real activities to digital activities. This phenomenon is a technology distribution (Sutrisno, 2019). The technology distribution answers the needs of the industrial revolution of 4.0. In the era of the industrial revolution 4.0 , it will change the way the global economy affects the education system. A sound education system will impact human resources' competence, which is required to be more innovative and creative to get involved in the employment field. It will change the concept of education through improving the quality of education to give birth to a competent generation (Hutapea Erwin, 2019).

The role of technology in improving the quality of education in the challenges of the industrial revolution 4.0 is closely related to the emergence of information technology in applications developed to support the learning process. The movement of technology also affects Japanese language learning. Many media learning applications can be downloaded on platforms such as the Play Store or the App Store. For example, there are applications to learn to read kanji, practice JLPT (Japanese Language Proficiency Test) questions from Level 1-5, practice Japanese conversation, listen to Japanese audio, and many more. Some of the learning applications mentioned above rarely provide digital books in Japanese.

The use of digital book provider applications in Japanese language lessons is still rarely used in educational institutions. One of which is extracurricular activities at Senior High School (SMAN) 7 Yogyakarta. Currently, textbooks have shifted and are replaced by electronic books (Puspita and Irwansyah: 2018). This issue also affects the reading interest of students at SMAN 7 Yogyakarta. The researcher took 20 students to determine the students' interest in reading Japanese text through the graph. 


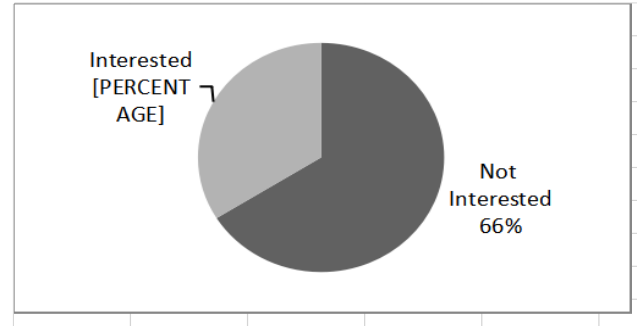

Figure 1 Percentage of Students' Interest at SMAN 7 Yogyakarta in Reading Japanese Text

The graphic shows that students interested in reading Japanese texts at SMAN 7 Yogyakarta is still low. Around $66 \%$ of students stated that reading Japanese texts was done during lessons only. Students preferred watch dramas, anime and play games outside of lessons. Reading is tedious if the content is not attractive. It is indicated by the number of students who prefer to watch anime, drama, and play games. Also, internal factors that motivate students to be reluctant to read other than in-class hours are the lack of books available in the library and conventional learning activities. Thus, this issue becomes a background that makes a-book reader application in Japanese, namely MAJIME (Mari Rajin Membaca/Let's Read Eagerly). This research focuses on using of this android application in reading Japanese in SMAN 7 Yogyakarta's extracurricular activities. Also, student responses to the use of the application. This study's results are expected to contribute to the education realm regarding Android-based digital media, which creates innovative and varied learning activities to face the Industrial Revolution's challenges.

\subsection{Literature Review}

Media are people, materials, or events that create conditions enabling students to acquire knowledge, skills, or attitudes (Gerlach \& Ely in Arsyad, 2014: 3). There are four functions of learning media, according to (Mc Kown in Rina, 2016). First, changing formal education; for example, abstract learning media into concrete, theoretical learning becomes practical functional. The second is to generate learning motivation. The third is to provide clarity so that the learners' knowledge and experience can be more explicit and more comfortable to understand; the media can clarify it. Finally, the fourth one is to stimulate learning, mostly the curiosity of students. Interest needs to be produced so that curiosity always arises.

The classification of media in the field of teaching Japanese varies according to the experts who classify them. One of them is in the book Nihongo Kyoojuhoo o Rikai Suru Hon (2011, 40-42). The types of media are as follows.

\subsubsection{Writing Media}

Writing media include textbooks, newspapers, magazines, novels, statistical data such as white books, various kinds of dictionaries, books of expertise, documents, advertising leaflets, pamphlets, travel schedules or lists, menu lists, flashcards (letter cards), role card, list of letters right.

\subsubsection{Audio}

Audio includes tape recorder and recordings about listening test.

\subsubsection{Audio Visual}

Audio visual includes video (VTR), film, software for CAI (computer-assisted instruction), and paper puppet plays.

\subsubsection{Media That Make Independently}

The result of creativity whose activities include games, role plays, projects.

\subsubsection{Technology-Based Media}

The media used uses technology designed to facilitate human activities.

Technology-based media is needed in learning innovation. There are many media for innovative learning in the form of applications. One of which is a digital book or E-book. The E-book is an electronic text that is available in a digitally encoded format readable via an electronic device (Wexelbaum, Miltenof, \& Paralaut, 2011). E-books will facilitate learning activities for reading comprehension in the Japanese language. However, E-books in Japanese is still minimal. Therefore, there is an application for E-book providers in Japanese developed, namely MAJIME (Mari Rajin Membaca/Let's Read Eagerly).

MAJIME is an android-based learning media that provides Japanese E-books. In its development, MAJIME applications will give various genres and language levels. This application feature supports Sketchware application creation technology and allows creators or application creators to create their applications. Therefore, researchers are free to add features to the MAJIME application. There are four features, namely about MAJIME, MAJIME Library, Vocabulary, and Quiz. The following is the appearance of the MAJIME application:

\subsubsection{About MAJIME}

About MAJIME contains a short guide and tips using the application. There is information on the copyright builder of the application, images, and books used. 


\subsubsection{MAJIME Library}

MAJIME Library contains a collection of children's storybooks in electronic form. The books that collected in this application are nine books with titles: (1) Issunboushi, (2) Urashimatarou, (3) Omusubi Kororin, (4) Kaguya Hime, (5) Kasajishou, (6) Saru Kani Gassen, (7) Shitakirisuzume, (8) Nezumi no Yomeiri, (9) Momotarou

\subsubsection{MAJIME Vocabulary}

There are two parts in this vocabulary section: the vocabulary that appears in the second reading, which introduces the kanji N5-N4.

\subsubsection{Quiz MAJIME}

In the MAJIME section, the quiz uses the Kahoot application facility to facilitate student competition to measure reading comprehension skills. The examination presented consists of two types of true and false questions, as well as multiple-choice questions.

The MAJIME application utilizes technology-based media types with an android-based visual multimedia concept. Using the android-based visual multimedia concept because it uses a controller in the form of an android smartphone to operate it. The components of making the MAJIME application are as follows:

\subsubsection{Smartphone}

Smartphones function as a device used to control all processes that will occur in using applications. Then the output of the application that is running will be displayed on the smartphone screen. The smartphone used is required to have an Android 9.0 operating system with a pie type.

\subsubsection{Adobe Illustrator}

Adobe Illustrator functions to combine designing images used for project layouts being worked on.

\subsubsection{Logo Designer}

Making an application logo on the MAJIME application uses the logo designer application. The logo implements a mix of symbols that stand out, namely $\mathrm{E}$ and a toga hat. The letter E symbol is education or the final letter of MAJIME.

\subsubsection{Sketchware}

Sketchware is an app builder software that can be uploaded on the Play Store. This application makes it easy for users to create their applications as desired. Since the available features are limited, programming language addition is needed to add functional features. Making the Sketchware application process requires a guide if the user is not a programmer. The manual can be obtained separately by downloading a licensed sketch or guided book. For those who already understand the programming language, doing a project in the Sketchware application should be practical. Still, when a layperson uses it, it is advisable to make a straightforward application so that the manufacturing process does not require programming language input.

The MAJIME application is equipped with interactive learning media where users can test their understanding of reading. The quiz uses the Kahoot application facility to operate and know the results immediately and thoroughly. The next feature is also the introduction of the kanji N5-N4 and vocabulary found in reading books. Tini and Sitti (2017) found the design of interactive E-book reader application with notification interruptions and E-book translator features from foreign languages. E-book reader application in an Android-based smartphone is more efficient, economical. It provides comfort without disturbing social media account notifications. Also, there is an Ebook translate in foreign languages into Indonesian. The trial results show that this application is easy to use, making it easier for users to read more efficiently than conventional books. This research presents the design E-book reader application in Japanese for reading learning media and applying it to students.

The previous research was conducted by Yee and Zainuddin (2018) on using E-books to improve reading comprehension in English. The result is that the use of E-book could improve understanding of reading comprehension among the students. Students had participated actively in the learning process and increased their level of motivation. Reid (2016) research found that E-book improved students reading comprehension. He found that E-book with attractive reading features helped students improve reading comprehension. Based on two previous research, this research attempts to determine whether the Japanese Ebook application, namely MAJIME, which can improve students reading comprehension of Japanese texts.

\section{RESEARCH METHOD}

This research used experimental methods. According to Sugiyono (2015:11), experimental research is a research method to find the effect of treatment (implementation) in certain groups. This method is to test the use of the MAJIME (Let's Read Eagerly) learning media application as a means of understanding the ability to read Japanese texts. This research employed a true experimental design by conducting a Pre-test - Posttest Class (Control Group Design). The experimental class provided treatment using learning media in the MAJIME application, while the control class did not provide treatment. The experimental design can be seen in the following chart. This research sample was extracurricular students of 
SMAN 7 Yogyakarta batch 2019/2020 with 32 people. Sixteen people in the experimental class and sixteen people in the control class.

The treatment in the experimental class used a cooperative learning method with a think-pair-share strategy. The application of MAJIME in the experimental class used the think-pair-share strategy to begin by creating groups. The meetings were held four times for the experimental class treatment and conducted one pre-test and one post-test. Sixteen people were involved in the meeting and they were divided into four groups, with four people for each group. These groups were asked to read the readings available on the application and to determine the information. Then, to determine how students comprehend the reading content, the group discussed and informed briefly about the reading content. After each group discovered the other groups' opinions, they worked on the quiz found in the MAJIME application.

Data collection techniques in this research used tests and non-tests. Tests in the experimental class and control class were collected data in test results in the pretest and posttest. Meanwhile, non-test data were in the form of questionnaires and interviews. In this research, data analysis techniques used the SPSS version $21+$ program to process parametric test instruments, test results, and questionnaires. This research hypothesized a significant difference between the experimental class's learning outcomes using MAJIME learning media and the control class that did not use those media.

\section{RESULT}

This research used test and questionnaire data analysis. The test was carried out in the control class and the experimental class with 16 people. The following are the stages of implementation activities in each class.

\subsection{Initial Activities}

The initial activity was carried out in the experimental class. The control class was an introductory activity. The delivery of lesson plans then was continued with guidance on working on pre-test questions. This activity aims to determine the extent of student achievement in learning to read Japanese.

\subsection{Core Activities}

Each class received the same pre-test and post-test questions, but the treatment given was different. The control class worked on questions using conventional reading techniques. In contrast, the experimental class worked on questions using the reading technique with the MAJIME application using Kahoot.

The use of the MAJIME application in the experimental class is as follows.

\subsubsection{Transfer the MAJIME application}

The transfer from MAJIME applications to students used Share It

\subsubsection{Install the application.}

After the application was transferred, the student pressed the install button. The application would be installed on the students' smartphones.

\subsubsection{Open the MAJIME Application}

After being installed, by pressing the open button, the first page of the MAJIME application was ready to use.

\subsection{Core Activities}

Experiment class students filled out a questionnaire after working on the questions. This questionnaire aimed to determine how the Japanese reading learning process and the use of the MAJIME application. At the end of the activity, the teacher closed the control class activities and the experimental class by completing the activity and providing motivation.

The result of the Data Test and Non-Data Test is below

\subsection{Data Test}

\subsubsection{Pretest Score in the Control and Experimental Class}

The maximum score for the control class was 75.5, and the minimum score was 25.0. The average obtained was 64.8. The range of values obtained in the control class was 50.5. Meanwhile, the maximum value of the experimental class students was 75.5. Furthermore, the minimum value was 37.5 , while the average was 69.53 . The range of values obtained in the experimental class was 38.0. The analysis results showed that the mean values of the two were not much different. Both did not meet the minimum completeness criteria (KKM) 75 , which means that the control class's initial ability and the experimental class still required intensive courses.

\subsubsection{Post-test Score in the Control and Experimental Class}


The post-test score of the control class was at least 37.0, and the maximum value was 75.5. The range of post-test scores for the control class was 38.5. The control class students' scores were not much different from the scores before the intensive class was conducted. Furthermore, the experimental class students' minimum score was 75.0, and the maximum

\subsubsection{Paired T-Test}

\subsubsection{Paired sample T-Test of Class Control}

The results of the paired sample t-test in the control class shows that the average pre-test score is 61.71 , and the average post-test score is 64.84 . This result shows a

Table 1. Paired Sample Test of Control Class

\begin{tabular}{|c|c|c|c|c|c|c|c|c|}
\hline \multicolumn{9}{|c|}{ Paired Samples Test } \\
\hline & \multicolumn{5}{|c|}{ Paired Differences } & $\mathrm{T}$ & Df & Sig (2-tailed) \\
\hline & Mean & $\begin{array}{l}\text { Std. } \\
\text { Deviation }\end{array}$ & $\begin{array}{ll}\text { Std. } & \text { Error } \\
\text { Mean } & \end{array}$ & $\begin{array}{r}95 \% \\
\text { Interval of }\end{array}$ & $\begin{array}{l}\text { Confidence } \\
\text { e difference }\end{array}$ & & & \\
\hline & & & & Lower & Upper & & & \\
\hline Pair 1 Pretest - Posttest & 3.12500 & 28.32108 & 7.08027 & 18.21624 & 11.96624 & 441 & 15 & .665 \\
\hline
\end{tabular}

score was 100.0 , while the average was 82.03 . The range of students' scores from the experimental class was 25.0. The scores obtained by all students from the experimental class using MAJIME teaching media have met the minimum requirements $(K K M)$. Based on the two data analyzes above, the experimental class's posttest score is higher than the Post-test score for the control class.

\subsubsection{Normality Test}

\subsubsection{Normality Test in Control Class}

The value (sig. 2-tailed) of the control class 0.205 and 0.522 , which means more than 0.05 . Thus, it can be concluded that the pretest and posttest values of the control class are normally distributed.

\subsubsection{Normality Test in Experimental Class}

the value (sig. 2-tailed) of the control class 0.716 and 0.248 , which means more than 0.05 . Thus, the pre-test and post-test values for the experimental class are normally distributed. comparison and an increase in the average between the Pre-test and Post-test classes by 3.12 points. The score of 3.12 is obtained from the results of processing the table data, which is presented below:

Based on the table, the $t_{\text {count }}$ is 441 , and the $d f$ is 15 . Thus the $t_{\text {table }}$ obtained is 2.119 . Therefore, the results of $t_{\text {count }}$ are to be higher than $t_{\text {table }}$, meaning that there is a significant difference between the pre-test and post-test scores in the experimental class.

\subsubsection{Paired Sample T-Test of Experimental Class}

The results of the paired sample t-test in the control class show that the pre-test means the score is 69.53 , and the post-test is 82.03 . These results indicate that there is an increase in the average of the pre-test and post-test. The comparison results showed an increase in the average between the pre-test and post-test experimental classes by 12.5 . The score of 12.5 can be read from the data processing above, which is presented in the table below:

Table 2. Paired Sample Test of Experimental Class

\begin{tabular}{|c|c|c|c|c|c|c|c|c|}
\hline \multicolumn{9}{|c|}{ Paired Samples Test } \\
\hline & \multicolumn{5}{|c|}{ Paired Differences } & \multirow[t]{3}{*}{$\mathrm{T}$} & \multirow[t]{2}{*}{ Df } & \multirow[t]{2}{*}{ Sig (2-tailed) } \\
\hline & Mean & $\begin{array}{l}\text { Std. } \\
\text { Deviation }\end{array}$ & $\begin{array}{|ll|}\begin{array}{l}\text { Std. } \\
\text { Mean }\end{array} & \text { Error } \\
\end{array}$ & $\begin{array}{r}95 \% \\
\text { Interval of } \\
\end{array}$ & $\begin{array}{l}\text { Confidence } \\
\text { le difference }\end{array}$ & & & \\
\hline & & & & Lower & Upper & & & \\
\hline Pair 1 Pretest - Posttest & 12.50000 & 19.36492 & 4.96980 & 2.18116 & 22.81884 & 2582 & 15 & .021 \\
\hline
\end{tabular}

\subsubsection{Test of Homogeneity of Variance}

The significance score using Levene Statistics shows that the sig score in the pre-test and post-test is 0.153 and 0.665 , which means more than 0.05 . Thus, the two classes have homogeneous variants.
From the table, the $\mathrm{t}_{\text {count }}$ is 2582 , and the $d f$ is 15 ; thus, the $t_{\text {table }}$ obtained is 2.119 . Thus, the results of $t_{\text {count }}$ can be said to be greater than $t_{\text {table, }}$ which means there is a 
significant difference between the pre-test and post-test scores in the experimental class.

\subsubsection{Independent Sample Test}

The post-test average mean score shows that the experimental class score is higher than the control class's average score by 61.71. The Post-test score difference ranged between the two classes is by 20.32 . This result shows that the ability to understand the reading between the two classes is significant.

Based on an independent sample test, the $t_{\text {count }}$ score is 3.175 , and the $d f$ is 30 ; thus, the table obtained is 2.119. Therefore, the $t_{\text {count }}$ results are more significant

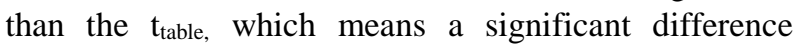
between the experimental class's posttest score and the control class.

\subsubsection{Result of Learning Affectiveness}

The criteria for determining the learning effectiveness used the normalized gain formula for the pre-test and post-test in the control and experimental classes. The obtained normalized gain in the control class was 0.07 , meaning that conventional reading methods are less effective in improving the ability to understand Japanese text. However, the obtained normalized gain ${ }_{1}$ in the experimental class was 0.56. Using learning media android MAJIME is more effective than conventional teaching methods.

\subsubsection{Hypothesis Testing}

The hypothesis test result showed that the hypothesis Ha was accepted, and Ho was rejected if $t_{\text {count }}>t_{\text {table }}$ and normalized gain ${ }_{1}>$ normalized gain 2 was proven correct. Ha reads the use of MAJIME learning media is effectively in improving reading skills and the ability to understand Japanese reading for the students. Ho reads that the use of MAJIME learning media was not effective in improving reading skills for the students.

The t-count obtained in the study was 3.175 , with the t-table comparison of 2.119. Then the normalized gain obtained in the control class was 0.07. However, the normalized gain1 results obtained in the experimental class were 0.56 . Thus, it can be concluded that using MAJIME android-based teaching media was significant.

\subsection{Non-Data Test}

Non-test data were in the form of a questionnaire developed by the researchers, which containing student responses about the impression of learning using the MAJIME. The questionnaire was distributed to the experimental class with open and closed questionnaires. There were ten questions in the closed questionnaire and four questions in the open questionnaire. From the closed questionnaire, $68.8 \%$ of students stated reading
Japanese text was boring, and $75 \%$ of students said it was difficult to get interesting that reading. So, $87.5 \%$ of students thought that the MAJIME media increased interest in reading Japanese because it was practically used whenever and wherever. $93.8 \%$ of students also agreed that the MAJIME media made it easier to understand Japanese reading. The students thought that MAJIME media could be an alternative medium for learning Japanese reading comprehension.

In the open questionnair data results, all students liked to learn Japanese texts using the MAJIME application. The books had pictures that made it enjoyable to understand Japanese culture through children's stories. Most students did not experience difficulties operating the MAJIME application because it has been explained in the application. Besides that, the instructor was very clear in conveying instructions.

\section{FINDING AND DISCUSSION}

The implementation of MAJIME learning media was carried out by pre-test, post-test, and three times treatment for the control class and the experimental class. On the pre-test scores, the control class's maximum score was the same as the experimental class, which was 75.5 , and the mean score of the control class was smaller than the experimental class. The pre-test results have met the minimum completeness criteria, namely 75 . However, the average score was still low for the control class and the experimental class. On the post-test scores, the control class students' maximum score was 75.5, while the maximum score for the experimental class students was 100 .

The average score of the control class is smaller than the experimental class. Based on these data, the experimental class's post-test value was higher than the control class's post-test value. There was difference in understanding Japanese text between students in the control class and experimental class. The pre-test score in the experimental class was 75.5, and the post-test score was 100 . It could show that there is a remarkable improvement in Japanese reading comprehension for students by using MAJIME learning media. According to Yee and Zainuddin (2018), using an E-book helps students improve their English reading comprehension. Their research was based on the pre-test score and posttest score. The pre-test score increased from 45.83 to 93.3 in the post-test, indicating positive improvements in their understanding and reading responses.

This research hypothesizes a significant difference between the experimental class's learning outcomes using MAJIME learning media and the control class not uses that media. The results of the hypothesis show that using MAJIME learning media is significant. In the test of the learning effectiveness criteria, the results showed that the use of MAJIME learning media was more 
effective than learning activities that used conventional methods. According to Reid (2016), E-book has a more significant impact on helping students' reading comprehension skills than a print copybook. Before students began interacting with eBooks, students were given pre-reading assessments using print copy books to test their reading retell comprehension skills. Then, students interacted with the eBooks and the enhanced interactive features included with the eBooks. Students were to read a book off of the eBook, and he tested again on retell. More than half of the students went up in retell comprehension scores. Therefore, his study concluded the fact that eBooks were a more beneficial tool to use for reading comprehension.

Many learning methods improve Japanese reading comprehension. One of them is the Peer Reading method. According to Sukmara (2020), the application of Peer Reading is useful for learning Japanese reading. Based on the average pre-test and post-test scores, It is known that the pre-test value before being given treatment is 70.84 . The post-test value after treatment was 82.42 with a gain value of 0.41 . This technique has a moderate level of effectiveness, so it can be concluded that the Peer Reading method is effective against understanding Japanese reading in students. However, the learning method using MAJIME media application is more effective than the Peer Reading method. It is indicated by the post-test results on the Peer Reading method, which was smaller by 82.42 with a gain value of 0.41 . The post-test results on the method using MAJIME learning media were 100 with a gain value of 0.56 .

The students enjoyed reading in MAJIME application and passionate about reading Japanese text. The vocabulary contained in the application made it easier for students to understand reading Japanese text. When implementing MAJIME learning media, the researchers found the disadvantages and advantages of using this application. The disadvantages are (1) this application cannot be downloaded freely and can only be transferred at a short distance using the share it or share me application, (2) The letters contained in the vocabulary feature are too small, (3) MAJIME application cannot be operated on Android, which is below version 9 and IOS (iPhone OS). Furthermore, the advantages are, (1) The E-book presented is pictorial therefore almost all students like to read Japanese texts, (2) MAJIME application is practical and can be read anywhere using a smartphone, (3) It can add insight into Japanese culture and reading skills.

MAJIME (Mari Rajin Membaca/Let's Read Eagerly) learning media has the concept of MVP (Minimum Viable Product). This term is often referred to in the start-up business, an example of its retail application. The definition of MVP is a new product with simple features that can provide maximum results to meet basic needs (Eric, 2009). In the formation of this application only use simple features that want to maximize reading needs. In the future, it is recommended that the development of this application only function as a Japanese E-book provider.

This application still requires various software to create it. Alpha build is software that helps with graphic design from Photoshop, Logo Designer, and Pic art. This application also utilizes Kahoot's facilities as a quiz builder application. This application development is recommended to use the latest version as a complement by reducing existing features. This study only focuses on the MAJIME learning media's effectiveness for high school students to understand Japanese text. Further research is needed on reading lessons at the tertiary level with different book content in the future. Also, it can be used for research in developing MAJIME applications using additional audio as listening learning.

\section{CONCLUSION}

The use of MAJIME learning media is proven to be effective in improving student learning outcomes in reading Japanese texts for extracurricular students at SMAN 7 Yogyakarta batch 2019/2020.

All students claimed to be convenient to read Japanese text using MAJIME because it is interesting to learn Japanese culture through pictorial stories. Moreover, it can be read practically anywhere, using a smartphone with a flexible time. It can help improve competency in reading Japanese text trough available quizzes.

\section{REFERENCES}

[1] A. Arsyad, "Media Pembelajaran," PT. Raja Grafindo Persada, 2014.

[2] G. Ayu Puspita and Irwansyah, "Indonesia: Studi Kasus Pembaca E-Book Melalui Aplikasi iPusnas," J. Kaji. Perpust. dan Inf., vol. 2, pp. 13-20, 2018.

[3] R. A. Azmuddin, N. F. M. Nor, and A. Hamat, "Facilitating online reading comprehension in enhanced learning environment using digital annotation tools," IAFOR J. Educ., vol. 8, no. 2, pp. 7-27, 2020, DOI: http://doi.org/10.22492/ije.8.2.01

[4] Y. Bee Choo and N. S. Zainuddin, "the Use of EBook To Improve Reading Comprehension Among Year 4 Pupils," J. English Educ., vol. 3, no. 1, pp. 23-32, 2018, DOI: http://doi.org/10.31327/jee.v3i1.477

[5] E. Hutapea, "Masuk Era Revolusi Industri 4.0 butuh 10 keterampilan ini," Kompasiana, 2019. 
https://edukasi.kompas.com/read/2019/07/09/1937 1911/masuk-era-revolusi-industri-40-butuh-10keterampilan-ini.

[6] C. Reid, "E-Books and Print Books Can Have Different Affects on Literacy Comprehension," Educ. Masters, vol. 5, pp. 1-72, 2016, https://fisherpub.sjfc.edu/cgi/viewcontent.cgi?articl $\mathrm{e}=1329 \&$ context=education_ETD_masters

[7] S. Rianti, H. Akhsan, and I. Ismet, "Development Modern Physics Digital Handout Based on Technology Literacy," Berk. Ilm. Pendidik. Fis., vol. 8, no. 1, p. 23, 2020, Doi: http://doi.org/10.20527/bipf.v8i1.7593

[8] Sugiyono, Metode Penelitian Pendidikan (Pendekatan Kuantitatif, Kualitatif, dan R\&D)," Alfabeta, 2015.

[9] R. Sukmara, "Efektivitas Peer Reading terhadap Kemampuan Pemahaman Dokkai Bahasa Jepang," J. Japanese Lang. Educ. Linguist., vol. 4, no. 2, pp. 177-186, 2020, doi: 10.18196/jjlel.4242.
[10] Sutrisno, "Era Disrupsi Teknologi Pentingkah Pendidikan Formal," Kompasiana, 2019. http://www.kompasiana.com/apoteksyafana/5db1e b26097f364cb14c6602/era-diprupsi-teknologipentingkah-pendidikan-formal.

[11] Tinni, A. Sitti, "Rancang Bangun Aplikasi E-book Reader dengan Interupsi Notifikasi dan Fitur Penerjemahan E-book dari Bahasa Asing Berbasis Android,", 2017.

[12] M. Yooko, "Nihongo Kyoojuhoo O Rikai Suru Hon," Tokyo, Baberu Puresu, 2002. 